\title{
Neogene and Quaternary geodynamic evolution of the Italian peninsula: the contribution of paleomagnetic data
}

\author{
Antonio Meloni, Laura Alfonsi, Fabio Florindo, Leonardo Sagnotti, Fabio Speranza and Aldo Winkler \\ Istituto Nazionale di Geofisica, Roma, Italy
}

\begin{abstract}
Paleomagnetism has played an important role in the development of geodynamic models for the Italian peninsula. Paleomagnetic data from this area have been increasingly reported since the late 1960s, placing important constraints on geodynamics. A brief outline of the main concepts underlying a paleomagnetic study is provided in the first part of this paper. We also discuss the criteria for the assessment of the reliability of paleomagnetic data. Finally, the data collected over the past 25 years in peninsular and insular Italy are synthetically reviewed, discussing the main implications for the geodynamic evolution of the Tyrrhenian - Apennines foreland system.
\end{abstract}

Key words paleomagnetism - geodynamics Italy

\section{Introduction}

Paleomagnetism is a relatively young geophysical science that includes aspects of geomagnetism and rock magnetism. Advances in this discipline include a better understanding of the Earth's magnetic field, its generation and time evolution, improvements in solid state physics and the knowledge of the magnetization processes in minerals and rocks, and in the stability of magnetization components through geological time. Paleomagnetism has several applications over a wide variety of Earth science problems. Geodynamics is one of the best known applications of paleomagnetism and in fact paleomagnetic studies were crucially im-

Mailing address: Dr. Antonio Meloni, Istituto Nazionale di Geofisica, Via di Vigna Murata 605, 00143 Roma, Italy; e-mail: meloni@marte.ingrm.it portant in reviving interest in continental drift in the 1950s and early 1960s and have since been fundamental in geodynamic reconstruction at different scales. After Blackett, Runcorn, Irving, Creer and others in the late $1950 \mathrm{~s}$ first showed with paleomagnetic measurements from Europe, North America, India and Australia that such continents underwent displacement and inferred the opening of the Atlantic Ocean, most work was carried out in stable continental areas to define motions of the cratonic parts of continents. The discovery of movements of these large crustal blocks led to the concept of Apparent Polar Wandering, APW (for a review of the historical background, see Le Grand, 1989; Opdyke, 1995).

In this framework another key result was the recognition that positive and negative lineated marine magnetic anomalies represented reversals of the Earth's magnetic field (see Glen, 1982). The following insertion in the plate tectonics scheme has enriched the results from continental rocks (see Gordon and Acton, 1989) and paleomagnetism still presently plays 
a fundamental role in global geodynamic models (e.g., Gordon, 1995). Paleomagnetism holds a special place in geophysics also because it is not only concerned merely with the present Earth, as most branches of geophysics are, but with the history of the Earth's solid surface and deep interior over millions and millions of years (for the aspects concerning the history of the Earth's magnetic field the reader is referred to the comprehensive reviews by Merrill and McElhinny, 1983 and McFadden and Merrill, 1995).

In the last 20 years or so paleomagnetism has also played an increasing role in geodynamic studies on a more localized scale, dealing with the identification of rotations about the vertical axis of smaller crustal blocks and with the diffused deformation in the plate boundaries and orogenic belts (e.g., Van der Voo and Channell, 1980; Lowrie and Hirt, 1986); this latest application is of particular concern in the Mediterranean area (e.g., Morris and Tarling, 1996).

In this paper we briefly outline the basic concepts of paleomagnetism study applied to geodynamics and we present some criteria for assessing the reliability of paleomagnetic data (see the classical texts by McElhinny, 1973; Collinson, 1983; Tarling, 1983; Butler, 1991; Van der Voo, 1993). We then synthetically review the available paleomagnetic data for peninsular and insular Italy. The purpose of this review is to provide an up-to-date summary of the paleomagnetic studies carried out during the past 25 years and to assess their main geodynamic implications for the reconstruction of the main geodynamic events.

\section{Natural Remanent Magnetization (NRM) of rocks and progressive stepwise demag- netization}

Paleomagnetism is essentially the study of the remanent magnetization of rocks. Rocks acquire a natural remanent magnetization mainly by three processes:

- Thermoremanent Magnetization (TRM) A remanence produced by cooling in a magnetic field from the Curie point to room tem- perature; TRM is typical of igneous rocks (deriving from consolidation of magma at any pressure). In the case of plutonic intrusions (low cooling rate), the remanence is acquired over a long time interval (paleomagnetic samples average out secular variation); in the case of volcanics (fast cooling rate), the remanence is acquired «instantaneously» (paleomagnetic samples record a spot-reading of the Earth's magnetic field).

- Depositional Remanent Magnetization (DRM) - A remanence acquired during or shortly after deposition of magnetic grains in water in the presence of a magnetic field. Typical of sediments. The sedimentation rate determines the extent to which secular variation is averaged out in a standard paleomagnetic sample (generally the secular variation is completely averaged in about $10^{4}$ years).

- Chemical Remanent Magnetization (CRM) - A remanence acquired when a magnetic mineral either nucleates or grows through a critical size or grows at the expense of a parent magnetic phase in a magnetic field, at constant temperature $\left(T<T_{\text {curie }}\right)$. Typical of alterations of pre-existing rocks (weathering, authigenesis, changes of $T, P$, ph....).

There are specific laboratory treatments on paleomagnetic specimens that aim at the recognition of all the magnetization components, particularly their direction and stability range. This is routinely achieved through a cycle of remanence measurements in progressive demagnetization steps. There are two demagnetization treatments that are commonly employed in paleomagnetic laboratories:

- Alternating Field (AF) demagnetization: demagnetization effected by a field of alternating polarity and smoothly decreasing amplitude; the peak field increases with each step of the demagnetization procedure. The contribution to the total remanence is gradually removed according to the coercivity spectra of the magnetic grains population in a standard paleomagnetic specimen.

- Thermal demagnetization: demagnetization effected by zero-field heating and cooling to room temperature; the peak temperature increases with each step of the procedure. The contribution to the total remanence is gradually 
removed according to the blocking temperature spectra of the magnetic grains population in a standard paleomagnetic specimen.

\section{Uncertainties in paleomagnetic data}

Paleomagnetic data have a statistical uncertainty about a mean direction. This uncertainty is particularly important when paleomagnetic data are employed to quantitatively evaluate crustal drifts and rotations and it places confidence limits on the obtained values. A short outline on the statistical grounds about paleomagnetic data is provided in the following.

\subsection{Fisher statistics}

Since paleomagnetic results can be thought of as directions penetrating a sphere of unit radius, it is common practice to use the properties of the Fisher (1953) distribution (assuming circularly distributed observations about a mean direction) for the scattering estimation.

The probability density distribution $(P)$ of an ideal population of directions on a sphere is

$$
P=\frac{\kappa}{4 \pi \sinh \kappa} \exp (\kappa \cos \phi),
$$

where $\kappa$ is the precision parameter and $\phi$ is the angle between the direction of a sample and the true mean direction. For a finite number of observations, $\kappa$ may be estimated by

$$
\kappa=\frac{N-1}{N-R},
$$

where $N$ is the number of observations and $R$ is the resultant sum of $N$ vectorially added individual unit vectors.

An alternative, very common, way to express uncertainty of paleomagnetic data is by means of the parameter $\alpha_{95}$, expressing the semi-angle of the cone of $95 \%$ of confidence about the mean direction:

$$
\alpha_{95}=\cos ^{-1}\left\{1-\frac{N-R}{R}\left[20^{\left(\frac{1}{N-1}\right)}-1\right]\right\} .
$$

\subsection{Paleomagnetic directions and virtual geomagnetic poles}

The principal assumption in paleomagnetism is that the geomagnetic field, if considered on time scales of the order of $10^{4}$ years or more, is dipolar and geocentric axial (GAD hypothesis). The geocentric hypothesis was confirmed by the analysis of paleomagnetic poles distribution for coeval samples coming from continental size distant areas. The GAD assumption was confirmed by the good agreement between paleomagnetic and paleogeographic determined poles; this was achieved by testing the alignment of the paleopoles and the geographical rotation axis in the geological past through the use of paleoclimatic indicators. For the last $100 \mathrm{Ma}$ the GAD assumption is granted to within an allowable deviation of no more than $5^{\circ}$.

In paleomagnetism it is usual to derive the parameters of the geocentric dipole which would give rise to the observed magnetic field direction at a given latitude $(\lambda)$ and longitude $(\phi)$. The geomagnetic pole of this imaginary dipole defines a Virtual Geomagnetic Pole (VGP). From spherical geometry VGP coordinates $\left(\lambda^{\prime}, \phi^{\prime}\right)$ can be determined given the coordinates of the sampling site $(\lambda, \phi)$ and its paleomagnetic direction, expressed in terms of declination and inclination $(D, I)$ (fig. 1 ):

$$
\begin{gathered}
\lambda^{\prime}=\sin ^{-1}(\sin \lambda \cos p+\cos \lambda \sin p \cos D) \\
\phi^{\prime}=\phi+\beta \text { for } \cos p \geq \sin \lambda \sin \lambda^{\prime} \\
\phi^{\prime}=\phi+\pi-\beta \text { for } \cos p<\sin \lambda \sin \lambda^{\prime} \\
\beta=\sin ^{-1}\left(\sin p \sin D / \cos \lambda^{\prime}\right) \text { for }-\pi / 2 \leq \beta \leq \pi / 2,
\end{gathered}
$$

where $p$ is the magnetic colatitude (given by $2-\cot p=\tan h$, that is the great-circle distance from site to the pole, and $\beta$ is the longitudinal difference between pole and site, positive toward the east. The fulfillment of these hypotheses, according to the above gives a precise paleogeographic meaning to $D$ and $I$ as recognized from paleomagnetic data.

Uncertainties statistically combine according to the geometry of a geocentric axial dipo- 


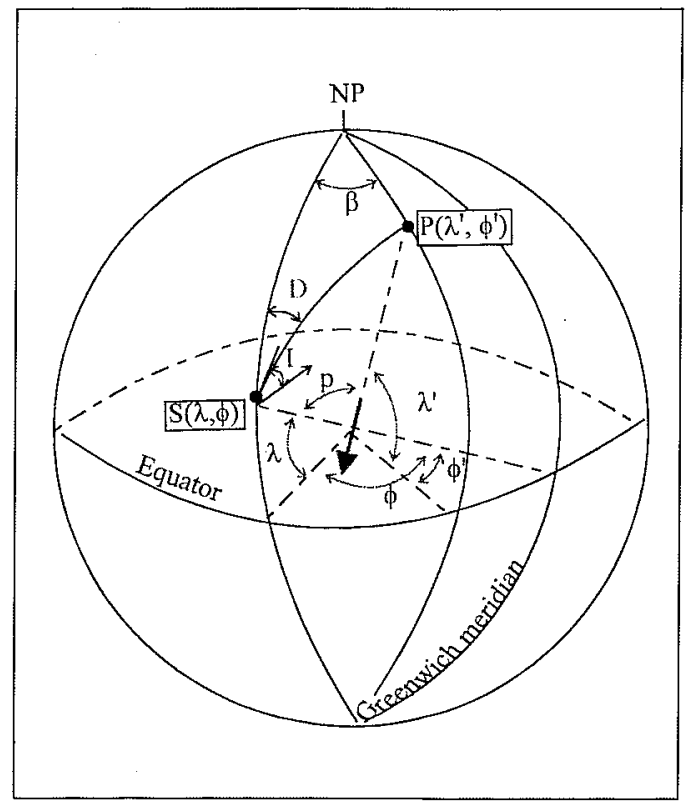

Fig. 1. Determination of magnetic pole position ( $P$ with coordinates $\lambda^{\prime}, \phi^{\prime}$ ) from a paleomagnetic field direction $(D, I)$ measured at a given site $(S$ with coordinates $\lambda, \phi$ ). The bold black arrow is the geocentric dipole that can account for the observed magnetic field direction.; $p$ is the magnetic colatitude (angular distance from $S$ to $P$ ) and $\beta$ is the difference in longitude between the magnetic pole and the site. NP is the north geographic pole. Redrawn after McElhinny (1973).

lar magnetic field on the Earth surface, so that a circle of confidence about a mean paleomagnetic direction obtained for a given site produces an ellipse of confidence about the VGP computed by the same paleomagnetic data (fig. 2a). Such ellipse has semi-axes $d m$ and $d p$ given by

$$
d m=\alpha_{95} \frac{\sin p}{\cos I} \quad d p=2 \alpha_{95}\left(\frac{1}{1+3 \cos ^{2} I}\right)
$$

where $p$ is the angle between the site and the pole (the colatitude) and $I$ is the paleomagnetic inclination.

A circle of confidence about a mean paleomagnetic direction at a given site converts in two distinct uncertainties for paleomagnetic declination $(D)$ and inclination $(I)$ (i.e., declination is badly defined at high latitudes, see fig 2b):

$$
\Delta D=\sin ^{-1}\left(\frac{\sin \alpha_{95}}{\cos I}\right) \quad \Delta I=\alpha_{95} .
$$

From a given VGP for a certain geological age an expected magnetic direction may be computed for each given site. Uncertainty on the VGP mean position (say $A_{95}$ the $\alpha_{95}$ value computed on a population of VGPs) produces uncertainties on the expected paleomagnetic direction $D_{x}$ and $I_{x}$ :

$$
\Delta D_{x}=\sin ^{-1}\left(\frac{\sin A_{95}}{\sin p}\right) \quad \Delta I_{x}=\frac{2 A_{95}}{1+3 \cos ^{2} p}
$$

\section{The reliability of paleomagnetic data}

Progress in rock magnetism analysis and data elaboration, has led in the past 40 years to an increase in the quality and significance of the paleomagnetic information; reliability criteria are however not generally codified and different requirements have been proposed by different authors (e.g., Van der Voo, 1990; Besse and Courtillot, 1991). Moreover, the reliability of paleomagnetic data according to present standards depends on the aim of the analysis. In particular, for geodynamic purposes, the main requirements are synthetically listed in the following:

\section{Sampling}

- Collection of several in-situ-oriented samples from a single outcrop (site).

- Collection of samples at several geographically distributed sites.

- Well-determined rock age.

- Averaging out geomagnetic secular variations.

- Structural control and a presumption of tectonic coherence with crustal structure involved (that is to avoid strongly deformed rocks). 


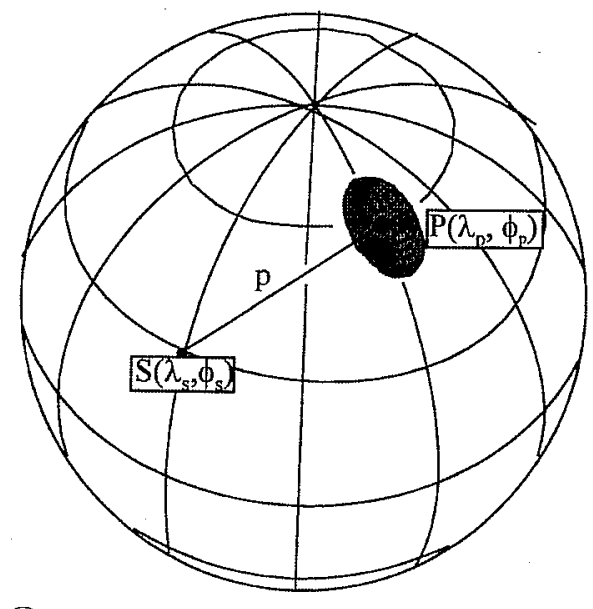

(a)

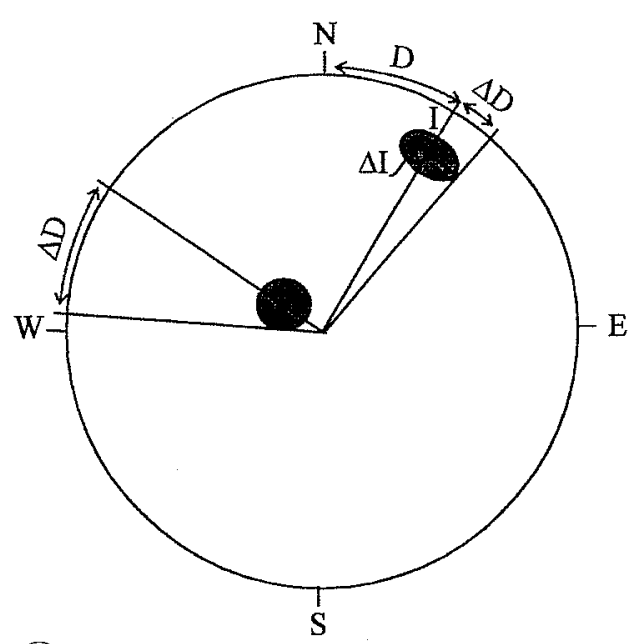

(b)

Fig. 2a,b. Uncertainties and confidence regions in paleomagnetic data. a) Ellipse of confidence about a VGP position ( $P$ with coordinates $\lambda_{p}, \phi_{p}$ ). $d p$ and $d m$ are the semi-axes of the confidence ellipse. $S$ is the sampling site with coordinates $\left(\lambda_{s}, \phi_{s}\right), p$ is the magnetic colatitude. Orthographic projection with latitude and longitude grid in $30^{\circ}$ increments. b) Equal area projection of directions ( $D=$ paleomagnetic declination, $I=$ paleomagnetic inclination) and attendant confidence limits $(\Delta D, \Delta I)$ for two representative paleomagnetic data. Redrawn after Butler (1991).

\section{Measurements}

- Adequate (stepwise) demagnetization of all specimens.

- Rock magnetism analyses for identification of the magnetic carriers.

\section{Data analysis}

- Adequate analysis of the demagnetization data (Principal Component Analysis and bestfit to the demagnetization paths - evaluation of the Maximum Angular Dispersion).

- Statistically sufficient number of useful data for computation. of paleomagnetic means.

- Field tests (e.g., the fold test) that constrain the age of magnetization.

- Presence of reversals and antipodality of Normal and Reversed directions.

- No resemblance to paleopoles of younger ages.

\section{Paleomagnetism and geodynamics}

A quantitative estimate of the entity and the history of lithospheric and crustal deformation can be inferred from paleomagnetic data. More exactly paleomagnetism is used in geodynamic studies to assess vertical axis rotations (by means of paleomagnetic declinations) and latitudinal drifts (by means of paleomagnetic inclinations). The applicability of the method covers a broad range of scales and ranges from plates (i.e., African plate), to microplates (i.e., Corsica-Sardinia), terranes (i.e., Wrangellia, along the Pacific coast of North America) and elementary geological structures (i.e., a single fold). In the orogenic belts the applications are mostly finalized to three distinct topics:

1) to estimate the pattern of vertical axis rotations and latitudinal translations of tectonic units that underwent different amounts of orogenic transport; 
2) to investigate the genesis of arcuate belts (that is testing the orocline hypothesis);

3) to reconstruct «true» orientation of stress and strain for deformational phases that affected rock units prior to rotation during orogenic transport.

However, some geodynamic problems cannot generally be solved easily by means of paleomagnetism. In particular, pure longitudinal translations are not directly resolvable from paleomagnetic data. Moreover, multiple phases of deformation may be actually superimposed on a measured paleomagnetic datum, so that what can be simply interpreted as a single vertical axis rotation may in reality be the resultant from the superposition of two (or more) distinct rotational phases. Finally, paleomagnetic data do not indicate directly the downward extent of the rotations found in the superficial cover.
Geodynamic applications of paleomagnetic data from relatively old sequences (e.g., Paleozoic or Mesozoic) in orogenic belts require the knowledge of a reliable reference paleomagnetic direction for an adjacent stable plate as a function of geologic time.

There are two possible approaches to compute vertical axis rotations and latitudinal drifts from paleomagnetic data:

1) Direction space approach, based on the comparison of the observed paleomagnetic direction with that expected from the nearby stable plate for a given period at the study locality (fig. 3a)

$R=D_{0}-D_{x}$ vertical axis rotation, positive clockwise;

$F=I_{x}-I_{0}$ flattening, or latitudinal drift.

2) Pole space approach, based on the comparison of the VGP computed by the observed

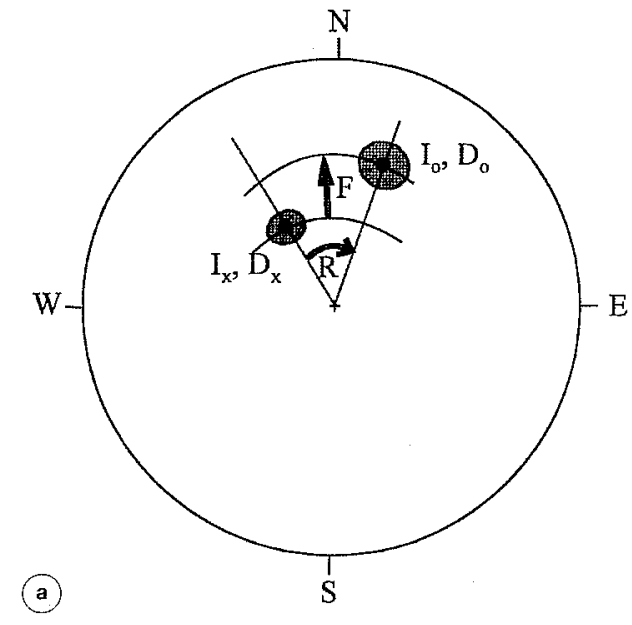

(b)

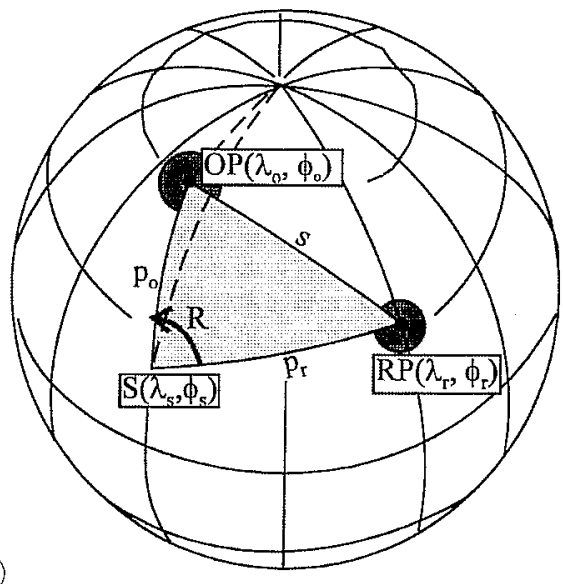

Fig. 3a,b. Estimates of vertical axis rotations and latitudinal drifts from paleomagnetic data. a) Directions space approach. Equal area projection, $I_{0}$ and $D_{0}$ are the observed paleomagnetic inclination and declination, $I_{x}$ and $D_{x}$ are the expected inclination and declination. $R$ is the vertical axis rotation, $F$ is the latitudinal transport; b) Pole space approach. $R P$ is the reference paleomagnetic pole at $\left(\lambda_{r}, \phi_{r}\right), O P$ is the observed paleomagnetic pole at $\left(\lambda_{0}, \phi_{0}\right), S$ is the site location at $\left(\lambda_{s}, \phi_{s}\right)$. The light stippled region is a spherical triangle with apices $S$, $O P$ and $R P$ and sides $s, p_{0}$ and $p_{r} . R$ is the vertical axis rotation. The poleward transport $p$ is given by $p=p_{0}-p_{r}$. Orthographic projection with latitude and longitude grid in $30^{\circ}$ increments. Redrawn after Butler (1991). 
paleomagnetic data with that expected from the Apparent Polar Wander Path (APWP) of adjacent stable plates (estimate of angles on a spherical surface, see fig. 3b).

The uncertainties related to the observed and reference paleomagnetic data produce uncertainties in the quantitative estimates of rotations and translations given by

$$
\Delta R=0.8 \sqrt{\Delta D_{0}^{2}+\Delta D_{x}^{2}} \quad \Delta F=0.8 \sqrt{\Delta I_{0}^{2}+\Delta I_{x}^{2}} .
$$

\section{A critical review of the available paleo- magnetic data in the Italian peninsula and islands}

The application of paleomagnetism to the study of the geodynamic evolution of the Italian peninsula has markedly evolved during the past 20 years. Most early studies concerned Mesozoic - lower Tertiary sequences and most of the early geodynamic concepts derived from paleomagnetic studies were drastically modified by the recent study of Neogene and Quaternary sequences throughout the peninsula. This was in part due to the advantages deriving from studying sequences contemporary to the main geodynamic events (table I).
This review has been organized into nine sections, separately taking into account the main Italian tectonic provinces (fig. 4). In particular, we will discuss the paleomagnetic data from the Corsica-Sardinia block (section 6.1), the Northern Apennines (6.2), the Tyrrhenian margin (6.3), the Central Apennines (6.4), the Southern Apennines (6.5), the Calabro-Peloritan block (6.6), the Sicilian belt (6.7), with a synthesis for the entire peri-Tyrrhenian arc (6.8) and the Adriatic and Iblean foreland (6.9).

The data from Mesozoic - lower Tertiary sequences were compared to coeval reference data extrapolated from the most recent versions of the European and African APWP (Besse and Courtillot, 1991; Van der Voo, 1993); indeed, the amounts of rotation recorded in these sequences remain controversial, since they critically depend on the nearby reference plate APWPs (e.g., Morris and Tarling, 1996; Channell, 1996). Moreover, the paleomagnetic data from the translated structures of the Apennines and the Sicilian belt were compared to the coeval data from the Adriatic and Iblean foreland. We emphasize that the amount of rotation experienced by the Adriatic block with respect to Africa is still debated (e.g., Lowrie, 1986; Van der Voo, 1993; Marton and Nardi, 1994;

Table I. A comparison between paleomagnetic data from «young» and «old» rocks in the Italian peninsula, with reference to the geodynamic applications.

\begin{tabular}{lcc}
\hline \hline & $\begin{array}{c}\text { Young rocks } \\
\text { (Neogene-Quaternary) }\end{array}$ & $\begin{array}{c}\text { Old rocks } \\
\text { (Mesozoic-Paleogene) }\end{array}$ \\
\hline $\begin{array}{l}\text { Age relationships with the main } \\
\text { geodynamic events }\end{array}$ & Coeval & Older \\
$\begin{array}{l}\text { Extensive remagnetizations } \\
\text { Multiple phases of rotation }\end{array}$ & $\begin{array}{c}\text { Unlikely } \\
\text { (fold test can rule out) } \\
\begin{array}{l}\text { Reference direction for } \\
\text { of the paleomagnetic data }\end{array}\end{array}$ & $\begin{array}{c}\text { Likely } \\
\text { (fold test cannot rule out) }\end{array}$ \\
$\begin{array}{l}\text { Conclusion } \\
\text { From GAD Earth's } \\
\text { magnetic field }\end{array}$ & Likely \\
\hline
\end{tabular}




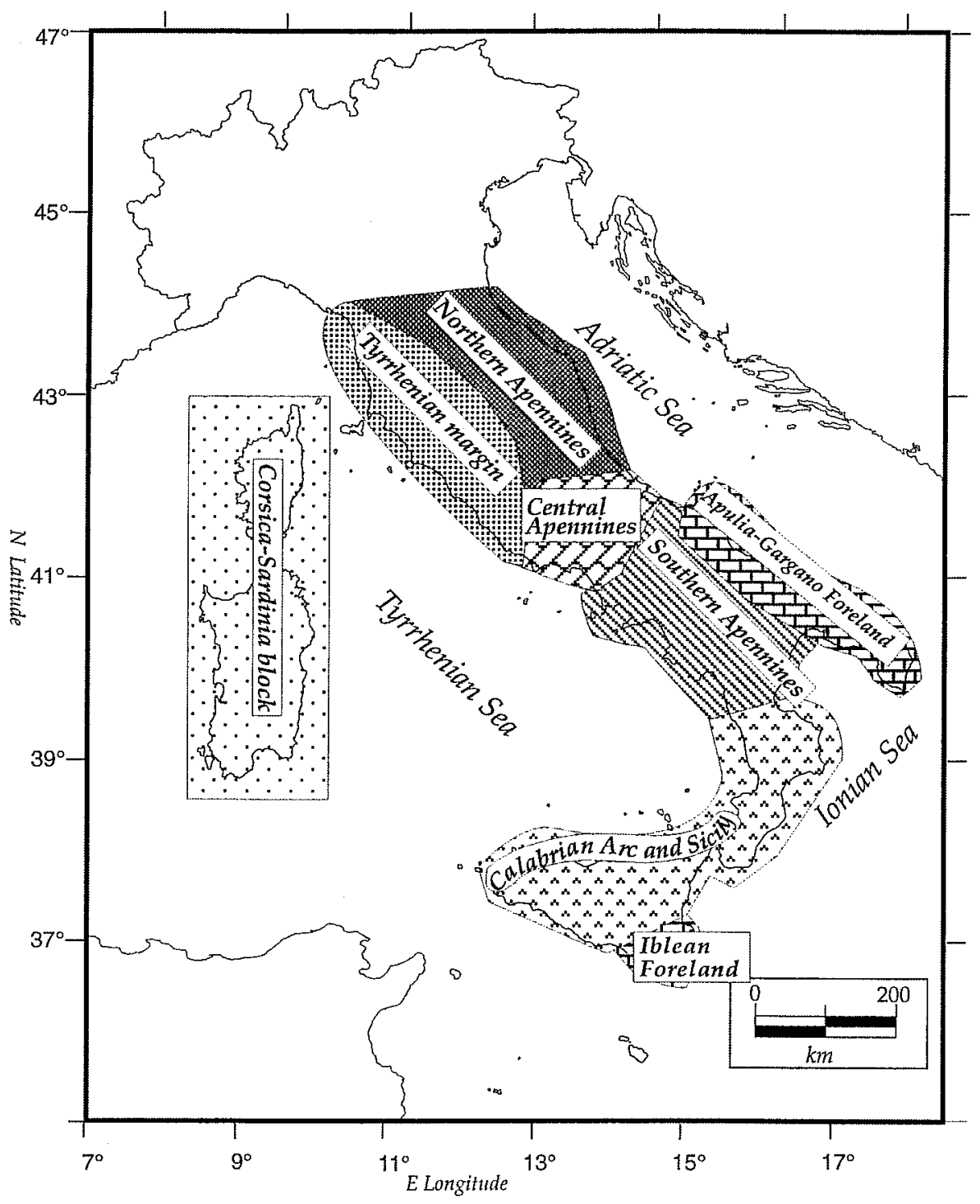

Fig. 4. Outline of the main tectonic provinces discussed in this review.

Channell, 1996). This implies that the rotation amounts in the Apennines with respect to the foreland are liable to revisions; however, we regret that the comparison of Mesozoic paleomagnetic data from Italy relatively to the African APWP is neglected even in very recent regional reviews (e.g., VanDijk and Scheepers, 1995).
Several geodynamic questions on the timing and the amount of rotation for the main structural provinces are still unsolved, notwithstanding the rich and reliable paleomagnetic data set; some answers may be found extending the paleomagnetic research and integrating evidence from different branches of the Earth sciences. 


\subsection{Corsica-Sardinia}

A first paleogeographic reconstruction in which the Corso-Sardinia block lies adjacent to Southern France was proposed by Emile Argand already in 1924. Different geological evidence was then found to support this hypothesis, which was subsequently accepted by many geologists, who proposed that the drifting of the Corsica-Sardinia block should imply a counter-clockwise (CCW) rotation of the two islands. These considerations obviously incited the production of paleomagnetic data; indeed, the Corsica-Sardinia block was the first paleo- magnetically investigated area in Italy and was the object of several studies in the 1968-1981 years (see table II). These studies concerned mainly Permian volcanics, Oligo-Miocene calc-alkaline sequences and Plio-Pleistocene basalts, whilst only a few studies (Horner and Lowrie, 1981; Vigliotti and Kent, 1990; Vigliotti and Langenheim, 1995) reported paleomagnetic results from sedimentary sequences (Mesozoic and Tertiary).

The paleomagnetic data, when compared with coeval reference directions from the European APWP, indicate a large $\mathrm{CCW}\left(60^{\circ}-70^{\circ}\right.$ in average) rotation of Corsica-Sardinia, roughly

Table II. Synthesis of paleomagnetic results from the Corsica-Sardinia block.

\begin{tabular}{|c|c|c|c|}
\hline Rock type and age & $\begin{array}{l}\mathrm{CCW} \text { rotation with } \\
\text { respect to Europe }\end{array}$ & References & Notes \\
\hline $\begin{array}{l}\text { Permian volcanics } \\
\text { and sediments }\end{array}$ & $\begin{array}{c}40^{\circ}-90^{\circ} \\
\left(60^{\circ}-70^{\circ} \text { in average }\right)\end{array}$ & $\begin{array}{l}\text { Nairn and Westphal (1968) } \\
\text { Zijderveld } \text { et al. (1970) } \\
\text { Westphal et al. (1976) } \\
\text { Storetvedt and Petersen (1976) } \\
\text { Storetvedt and Markhus (1978) } \\
\text { Edel et al. (1981) } \\
\text { Vigliotti et al. (1990) }\end{array}$ & $\begin{array}{l}\text { No rotation between Corsica } \\
\text { and Northern Sardinia } \\
\text { (Vigliotti } \text { et al., 1990) } \\
\text { Late Hercynian block rota- } \\
\text { tions in Sardinia? } \\
\text { (Edel et al., 1981) }\end{array}$ \\
\hline $\begin{array}{l}\text { Mesozoic carbonate } \\
\text { sequences }\end{array}$ & $\begin{array}{c}-90^{\circ} \text { after Trias } \\
\sim 70^{\circ}(? ?) \text { after Jurassic }\end{array}$ & Horner and Lowrie, 1981 & \\
\hline $\begin{array}{l}\text { Oligo-Miocene } \\
\text { volcanics }\end{array}$ & $\begin{array}{c}0^{\circ}-60^{\circ} \\
\left(30^{\circ} \text { in average }\right)\end{array}$ & $\begin{array}{l}\text { De Jong et al. (1969) } \\
\text { Bobier and Coulon (1970) } \\
\text { De Jong et al. (1973) } \\
\text { Bobier (1974) } \\
\text { Coulon et al. (1974) } \\
\text { Manzoni (1974) } \\
\text { Edel and Lortscher (1977) } \\
\text { Edel (1979) } \\
\text { Montigny et al. (1981) } \\
\text { Vigliotti and Langenheim (1995) }\end{array}$ & $\begin{array}{l}\text { Highly scattered data } \\
\text { Rotation occurred during } \\
\text { early-middle Miocene? }\end{array}$ \\
\hline Tertiary sediments & $\begin{array}{l}-30^{\circ} \text { after Eocene (1 site, } \\
\text { Corsica), } 0^{\circ}-10^{\circ}(?) \text { after } \\
\text { Burdigalian-Serravallian } \\
\text { (Sardinia) }\end{array}$ & $\begin{array}{l}\text { Vigliotti and Kent (1990) } \\
\text { Vigliotti and Langenheim (1995) }\end{array}$ & \\
\hline $\begin{array}{l}\text { Plio-Pleistocene } \\
\text { basalts }\end{array}$ & $0^{\circ}$ & $\begin{array}{l}\text { Bobier and Coulon (1970) } \\
\text { Manzoni et al. }(1972) \\
\text { Alvarez et al. }(1973) \\
\text { Coulon et al. }(1974)\end{array}$ & \\
\hline
\end{tabular}


$30^{\circ}$ of which presumably occurred during late Mesozoic - early Tertiary, and the other $30^{\circ}$ during Oligo-Miocene. Most of the authors proposed that the former rotational episode occurred together with the Cretaceous $30^{\circ} \mathrm{CCW}$ rotation of Iberia. In this case, the Corsica-Sardinia block was previously located to the south of the present Pyrenean belt, adjacent to the Northern Catalan coast, and the geological similarities found with the Provençal coast (Westphal et al., 1976) may be purely fortuitous.

Montigny et al. (1981) reviewed all the then available Oligo-Miocene paleomagnetic data, concluding that the rotation of the Corsica-Sardinia block was extremely rapid and mostly occurred in the Burdigalian, between 20.5 and $19 \mathrm{Ma}$ ago. This apparently decisive conclusion has recently been critically revised by Todesco and Vigliotti (1993) and new paleomagnetic data from Northern Sardinia volcanics and sediments dated at 20.5-18.5 Ma (Vigliotti and Langenheim, 1995) confirm that the exact timing of the Oligo-Miocene rotational event is not completely understood.

Finally, early paleomagnetic works suggested a differential Tertiary rotation of a decoupled Corsica-Sardinia block (Westphal et al., 1976), but recent paleomagnetic data suggest that the Corsica-Northern Sardinia block rotated as a whole (Vigliotti et al., 1990).

\subsection{Northern Apennines}

The Mesozoic - early Tertiary Scaglia Formation from the Umbria-Marche Apennines is, both for paleomagnetism and magnetostratigraphy, one of the most studied sedimentary sequences in the world, providing a long-standing influence on the development of most of the geodynamic models for the whole Italian peninsula and the «Adria» microplate. Indeed, the concepts of $\mathrm{CCW}$ «rotation of the Italian peninsula» and «African affinity» of Adria and its margins were born from the earliest paleomagnetic studies (Lowrie and Alvarez, 1974, 1975; Klootwijk and VandenBerg, 1975; VandenBerg and Wonders, 1976; VandenBerg et al., 1978) in this area. All these authors considered the Umbria-Marche units as «autoch- thonous» and assumed a large extrapolation of the vertical axis rotations there found to the whole Italian peninsula. However, the geodynamic interpretation of the paleomagnetic data from this region underwent substantial modifications (see table III), following the improvements in the knowledge of the general Apennine tectonics and of the major plate motion since the Mesozoic. Gradually the concept of «rotation of the Italian peninsula» was dismissed and the age of the rotation has considerably rejuvenated.

The origin of the arcuate shape of the Umbria-Marche Apennines represents a further long debated subject, that has been repeatedly tested by paleomagnetism. A mechanism of «oroclinal» bending (when the amount of rotation throughout the chain is structurally dependent) was first confirmed and then rejected according to different data sets from Mesozoic lower Tertiary sediments in the internal (Umbria-Marche) domain (Channell et al., 1978; Eldredge et al., 1985; Hirt and Lowrie, 1988). New data from Messinian sediments along the external (Marche-Romagna) domain suggest that at least the external arc is properly an «orocline», supporting the existence, during the Messinian, of a straight belt-foredeep system roughly oriented $\mathrm{N} 320^{\circ}$. It was found that vertical axis rotations are related to the Neogene-Quaternary emplacement of the Apennine thrust sheets (Speranza et al., 1997); nevertheless, the exact timing of the rotations after the early Pliocene, the driving geodynamic mechanism and the depth of the structures involved in this rotation are still unclear.

\subsection{Tyrrhenian margin}

The first paleomagnetic studies of the Tyrrhenian margin were carried out mainly to define the spatial and temporal extent of the vertical axis rotations already detected in the Apennines, considering the Tyrrhenian margin and Northern Apennines as a single structural province. The first data in this region were collected in the Triassic Verrucano Formation in Tuscany (VandenBerg and Wonders, 1976), inferring that the whole Italian peninsula 
Table III. Compendium of the main geodynamic interpretations for the paleomagnetic data from the Northern Apennines.

\section{Areal extent of the rotation}

Italian peninsula

Northern Apennines

Structural dependence through the belt (local tectonics and differential decollement)
Lowrie and Alvarez $(1974,1975)$

Klootwijk and VandenBerg (1975)

VandenBerg and Wonders (1976)

VandenBerg et al. (1978)

VandenBerg and Zijderveld (1982)

Channell and Tarling (1975)

Channell (1977)

Channell et al. (1978)

Van der Voo and Channell (1980)

Hirt and Lowrie (1988)

Channell (1992)

Speranza et al. (1997)

\section{Age of the rotation}

Late Cretaceous

(with respect to Africa)

2 phases of $\mathrm{CCW}$ rotation

Cretaceous $\left(45^{\circ}\right)$ and Eocene $\left(25^{\circ}\right)$

(with respect to Europe)

Coherence with Africa up to late

Cretaceous, followed by relative $\mathrm{CCW}$

rotation $\left(25^{\circ}\right)$ during early Tertiary

Late Tertiary

Neogene

Plio-Pleistocene
Klootwijk and VandenBerg (1975)

Lowrie and Alvarez (1974, 1975)

VandenBerg and Wonders (1976)

VandenBerg et al. (1978)

Channell et al. (1978)

Lowrie (1986)

Hirt and Lowrie (1988)

Channell (1992)

Speranza et al. (1997) was part of the African plate until the early Tertiary and subsequently it underwent a $25^{\circ}$ $\mathrm{CCW}$ rotation with respect to Africa and $15^{\circ}$ relatively to the Southern Alps. This conclusion was later rejected by Kligfield and Channell (1979) who stated that paleomagnetic data from the allochthonous Verrucano Formation «cannot be used to establish the autochthony of Umbria or the applicability of the Umbrian data to autochthonous Italy». Paleomagnetic data from this region were then used to assess that any rotation in the Umbria-Marche region should have been completed by the early Pliocene (Lowrie and Alvarez, 1979).

Recent studies (Sagnotti et al., 1994; Mattei et al., 1996a) on the Messinian-Pleistocene neo-autochthonous cycle sediments indicated no rotation for the Tyrrhenian margin since late Pliocene (fig. 5) and remarked that the Tyrrhenian margin and Northern Apennines actually are two distinct rotational domains. The new data show that (Mattei et al., 1996b): 1) the severe extensional, rifting and spreading processes which have occurred in the Tyrrhe- 


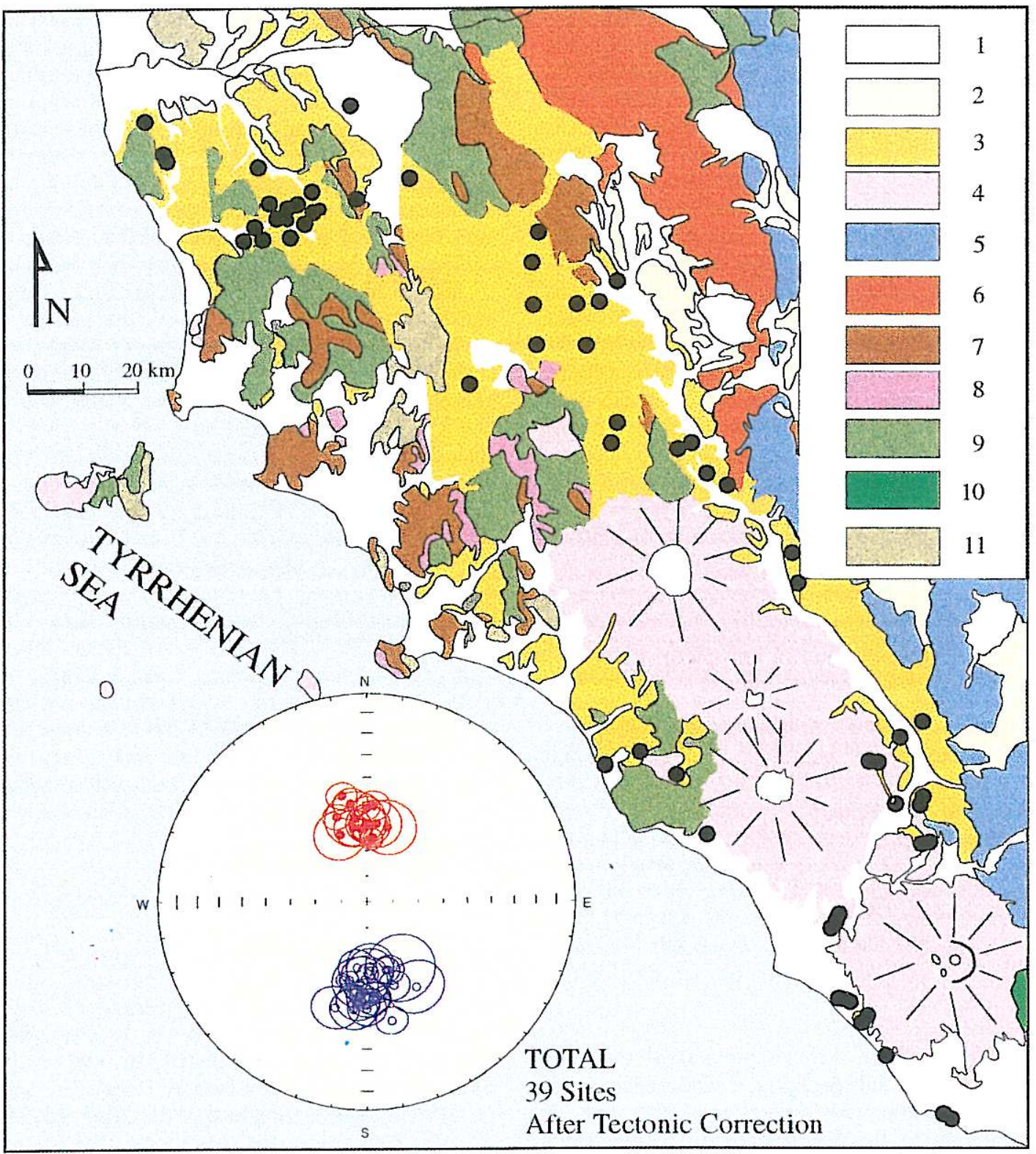

Fig. 5. Paleomagnetic sampling sites in the neo-autochthonous sequences of the Tuscan-Latium Tyrrhenian margin and equal-area projection of the paleomagnetic site mean directions. 1) Quaternary sediments; 2) Villafranchian sediments; 3) Miocene - Pliocene sediments; 4) Igneous rocks; 5) Umbria-Marche units; 6) Cervarola unit; 7) Tuscan unit; 8) Sub-Liguride units; 9) Liguride units; 10) Latium carbonate platform; 11) Metamorphic basement. Paleomagnetic data: open (blue) circle - reverse polarity; closed (red) circles - normal polarity. Redrawn after Sagnotti et al. (1994) and Mattei et al. (1996a). 
nian Sea since Messinian did not cause any tectonic rotation in the Northern-Central Tyrrhenian margin of the Italian peninsula; 2) the processes that produced shortening and large rotations in the Apennine thrust sheets were followed by an irrotational late-orogenic collapse.

\subsection{Central Apennines}

Paleomagnetic studies of the Central Apennines have been performed only in the past few years and they propose a complex, structuredependent, pattern of vertical axis rotations.

The results from the Cretaceous limestones of the Monte Maiella (Jackson, 1990) and Monte Greco-Monte Genzana (Marton and D'Andrea, 1992) structures, in the Eastern Abruzzi range, were interpreted in terms of a $25^{\circ}-40^{\circ}$ clockwise $(\mathrm{CW})$ rotation relatively to the Apulia foreland. However, lower Cretaceous data from these structures are not statistically distinct from the coeval reference direction estimated by the recentmost African APWPs and from coeval data from Gargano (see section 6.9).

Extensive sampling was carried out in Tertiary sediments along different structures (Dela Pierre et al., 1992; Mattei et al., 1995). The results point out that the observed wide variability in the structural trends is a consequence of a widespread and composite pattern of vertical axis rotations. The data from the late Cretaceous-Eocene Scaglia Formation in the Gran Sasso range (Dela Pierre et al., 1992) were interpreted as indicative of a differential CCW rotation (up to $90^{\circ}$ in the eastern sector) over the underlying, not rotated, Monti della Laga structures.

Two distinct rotational phases were identified in the other structures of the Central Apennines (Mattei et al., 1995). The first is a CCW rotation recorded in Eocene-Oligocene sediments; the second produced post-late Miocene differential block rotations according to different domains: CW rotations for the Southern Sabina, CCW rotations for the Latium-Abruzzi carbonate platform and $\mathrm{CW}$ rotations for the Marsica. This rotational pattern is referred to strike-slip faults and out-of-sequence thrust activity. Also in this case the exact timing of this rotational phase is unknown. Paleomagnetic evidence suggests that at the end of the Miocene the Central Apennines belt-foredeep system was roughly straight and oriented $\mathrm{N} 320^{\circ}$.

The first paleomagnetic data from continental Plio-Pleistocene sediments in the intermontane basins of the Central Apennines (Alfonsi et al., 1995) have been heavily affected by the presence of a strong viscous magnetization, and therefore they are not suitable for geodynamic interpretations.

\subsection{Southern Apennines}

The first paleomagnetic data from the Southern Apennines were collected over 20 years ago. This region has since been the focus of several paleomagnetic studies aimed at the reconstruction of the geodynamic evolution from the Jurassic to the Present, and in particular a better understanding of the Apennine mountain-building processes. The first studies concerned paleomagnetic results from Mesozoic (mainly sedimentary) rocks (Channell and Tarling, 1975; Manzoni, 1975; Incoronato, 1983; Incoronato et al., 1985; Incoronato, 1988; Incoronato et al., 1988; Iorio and Nardi, 1988; Jackson, 1990; Gialanella et al., 1991).

The sampled rocks were collected in a1lochthonous structures and the paleomagnetic data have been used to infer the amount of vertical axis rotations that accompanied the tectonic transport towards the Adriatic foreland. The paleomagnetic data from Mesozoic sediments are scarce and often of low-quality and indicate very different amounts of CCW rotation with respect to the coeval reference direction from the African APWP and the Adriatic foreland (fig. 6).

Some old paleomagnetic results have recently been re-evaluated in light of more rigorous analyses of the demagnetization data (Incoronato, 1988) suggesting that some structures possibly underwent a complex deformation history and multiple phases of rotations. Mesozoic paleomagnetic data were also re- 


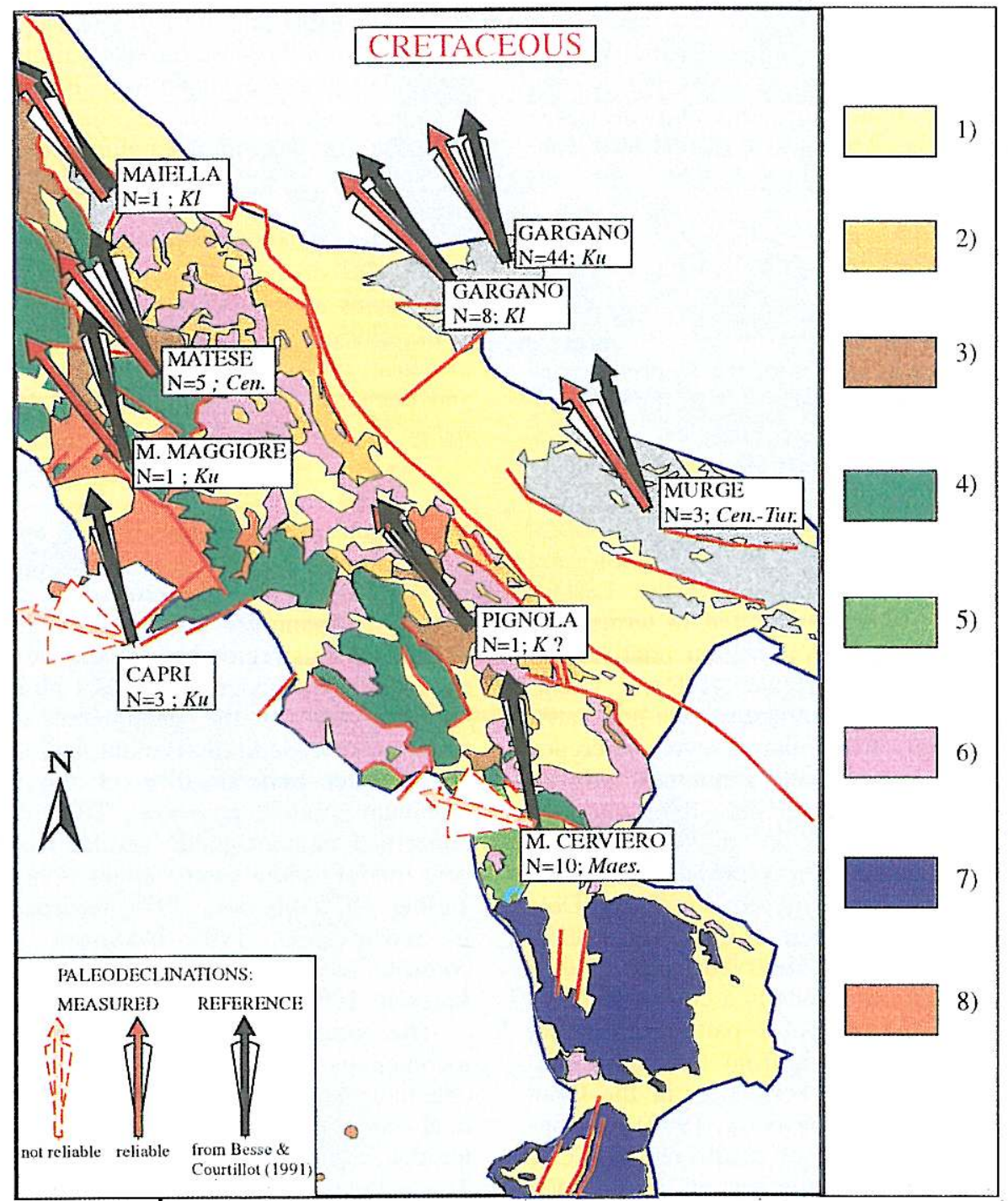

Fig. 6. Cretaceous paleomagnetic data from sediments in the Southern Apennines and the Apulian foreland. $\mathrm{Kl}=$ lower Cretaceous; $\mathrm{Ku}=$ upper Cretaccous; Cen. = Cenomanian; Tur. = Turonian; Maes. = Maestrichtian. Red dashed arrows and cones indicate paleomagnetic data (M. Cerviero, Capri) obtained by laboratory treatments not reliable according to present standards or highly scattered results. Black arrows represent the directions expected at each site location, when considered fixed to the African plate. Reference African directions and their confidence cones at each site were computed from the African pole list in the paper by Besse and Courtillot (1991), using the formulas shown in section 3.2. We emphasize that data collected from a single locality (M. Maiella, M. Maggiore, Pignola) are hardly representative of a whole structure. Schematic geologic map from Funiciello et al., 1981: 1) post-orogenic sedimentary sequences; 2) late orogenic flysch; 3) Mesozoic - early Tertiary basinal sequences; 4) Mesozoic - early Tertiary carbonatic platform sequences; 5) Verbicaro unit; 6) Allochthonous Liguride and Sicilide complexes; 7) Alpine units of the Calabride complex; 8) Plcistocene volcanics. 
cently interpreted as representative of local movements between adjacent structures, more than regional rotations (Gialanella et al., 1991). Finally, detailed rock magnetism analyses integrated with magnetic anisotropy studies pointed out that «anomalous» paleomagnetic data from Mesozoic carbonates may result from peculiar magnetic fabrics, probably related to internal strain and/or chemical remagnetization during the Tertiary main deformation events (Gialanella et al., 1994). This should explain the origin of too steep paleo-inclinations characterizing some paleomagnetic results from Mesozoic limestones (e.g., paleomagnetic data from Lagonegro in Incoronato et al., 1985 and from Monte Raparo in Jackson, 1990), which are difficult to understand in terms of simple tectonic deformations.
Only in the past few years were data obtained from Neogene and Quaternary terrigenous clayey sediments proving that large vertical axis rotations in the Southern Apennines (and also the Calabrian arc and Sicily, see next sections) occurred during Pliocene and Pleistocene times. These data outline a pattern of rotations that appears of regional significance (fig. 7).

Considerable $\mathrm{CCW}$ rotations $\left(\approx 24^{\circ}\right)$ occurred after the early Pleistocene in some basins of the Southern Apennines (Sagnotti, 1992; Sagnotti and Meloni, 1993; Scheepers and Langereis, 1994), whereas no rotation is recorded in the post-orogenic sediments of the Bradano cycle (Scheepers, 1992; Scheepers et al., 1993). A middle Pliocene-lower Pleistocene regional phase of about $15^{\circ} \mathrm{CCW}$ rota-
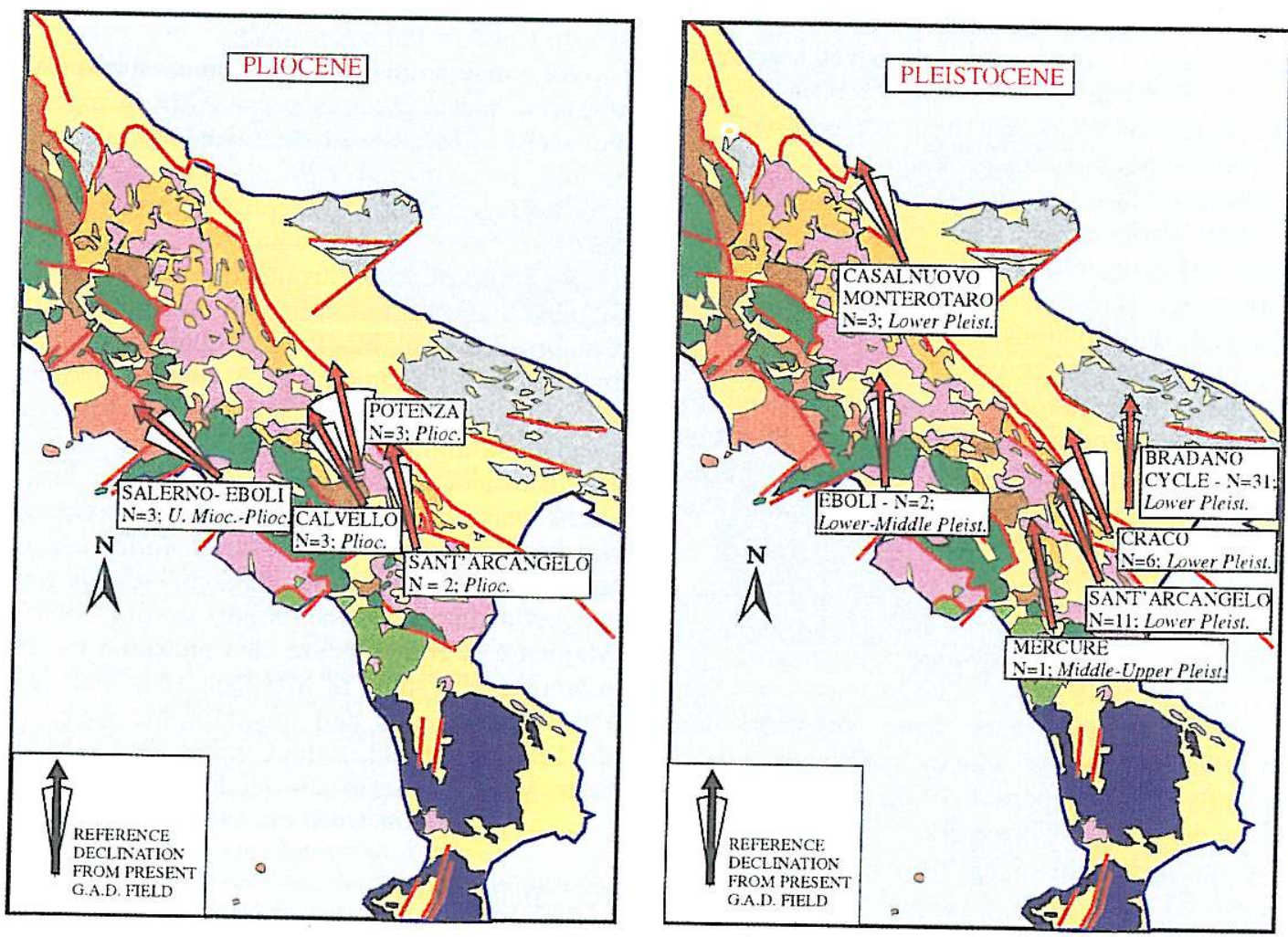

Fig. 7. Pliocene and Pleistocene paleomagnetic data from sediments in the Southern Apennines and the Apulian foreland. A confidence interval of $5^{\circ}$ was assumed for the reference GAD. Other symbols as in fig. 6 . 
tion was suggested by Scheepers and Langereis (1994), on the basis of the comparison of paleomagnetic data from sediments of late Messinian to late Pleistocene age, from different structures. However, this hypothetic phase is not substantiated by paleomagnetic data from the Sant'Arcangelo basin (Sagnotti, 1992; Sagnotti and Meloni, 1993), where it appears that all the recorded $\mathrm{CCW}$ rotations occurred after the deposition of the lower Pleistocene clays. On the other hand, in this basin different amounts of CCW rotations are recorded in sediments of the same age from sites geographically distributed in the eastern flank of the basin in an apparently regular trend increasing from north to south (Sagnotti, 1992; Scheepers et al., 1993). Paleomagnetic data for middlelate Pleistocene sediments are currently available for 4 sites only at two distinct localities (Scheepers and Langereis, 1994) showing no coherent rotational patterns: in the Eboli area no significant rotation was observed, whereas in the Rotonda area, in the Mercure basin, about $12^{\circ}$ of $\mathrm{CCW}$ rotation are recorded in continental lagoonal sediments of middle-late Pleistocene age.

The whole set of data currently available shows that the rotations detected in Mesozoic formations may, in some structures, reflect complex deformations resulting from competing and diachronous geodynamic phenomena. Further investigations are clearly needed to clarify the geographic and temporal distribution of tectonic rotations in the Southern Apennines and to better understand the dynamics of the deformation in this belt.

\subsection{Calabro-Peloritan block}

Paleomagnetic data from several sites in Plio-Pleistocene clayey sediments have recently been reported (Aiffa et al., 1988; Scheepers, 1994; Scheepers et al., 1994); relying on such data, a uniform $\mathrm{CW}$ rotation of about $15^{\circ}$ has been proposed for the whole Calabro-Peloritan block (Scheepers et al., 1994), taking place in an extremely short time interval, between 1 and $0.7 \mathrm{Ma}$ (VanDijk and
Scheepers, 1995). However, the observed widespread records for $\mathrm{CW}$ rotation (with values actually ranging from $0^{\circ}$ to $40^{\circ}$ ) depend strongly on the structural position of the sites as well as on the age of the studied sequences. This aspect deserves some additional comments; in particular, the data from Northern Calabria (Scheepers, 1994) show that the sites of the west flank of the Crati basin record relatively large $\mathrm{CW}$ rotations, whereas the coeval sites on the east flank of the basin appear. essentially not rotated. Moreover, two sections containing the Jaramillo subchron (dated at 0.990-1.070 Ma; Cande and Kent, 1995) provided very different results: one of them, on the west side of the Crati basin (San Marco Argentano) is rotated about $40^{\circ} \mathrm{CW}$, the other, on the north of the basin (Firmo) is not rotated. It is noteworthy that the Firmo and the east Crati sites constitute the «evidence» for placing an upper limit on the age of the rotation of the whole Calabro-Peloritan block!

We conclude that, though a generalized $\mathrm{CW}$ rotation during Pleistocene of the CalabroPeloritan block is well established, more data should be obtained before assuming robust conclusions concerning the actual timing of the rotation throughout the whole block.

Preliminary results from Miocene sediments suggest that rotations were not uniform for the Calabro-Peloritan block (Scheepers, 1994). A major CCW rotation $\left(\sim 90^{\circ}\right)$ episode in middle-Miocene was suggested on the basis of magnetostratigraphic analyses carried out at the Basilicoi section, in the Crotone basin (Scheepers, 1994), but this early interpretation has been very recently dismissed, following an integrated study of paleomagnetic results and magnetic fabrics (Duermeijer et al., 1996). Major CCW rotations are also indicated by the paleomagnetic study of Mesozoic sediments and Paleozoic igneous and metamorphic rocks in the Sila massif and in the Coastal Chain (Manzoni, 1979; Manzoni and Vigliotti, 1983).

\subsection{Sicilian belt}

Several paleomagnetic data are available for the Northern Sicilian chain and the Caltanis- 
setta basin. The data from the Mesozoic - lower Tertiary sediments in the West Sicilian fold and thrust belt collected over the past 20 years indicated large-scale $\mathrm{CW}$ rotations for the different paleogeographic units (Catalano et al., 1976; Schult, 1976; Channell et al., 1980; Nairn et al., 1985; Channell et al., 1990). The magnitude of the $\mathrm{CW}$ rotations detected in these studies decreases stepwise from over $120^{\circ}$ in the upper sheets (paleogeographically internal Panormide units) to almost no rotation in the frontal portion of the belt (external part of the Saccense unit) (fig. 8). These rotations have been related to thrusting and to changes in the direction of tectonic transport from easterly to southerly (Oldow et al., 1990).

The paleomagnetic data recently reported for some magnetostratigraphic sections in

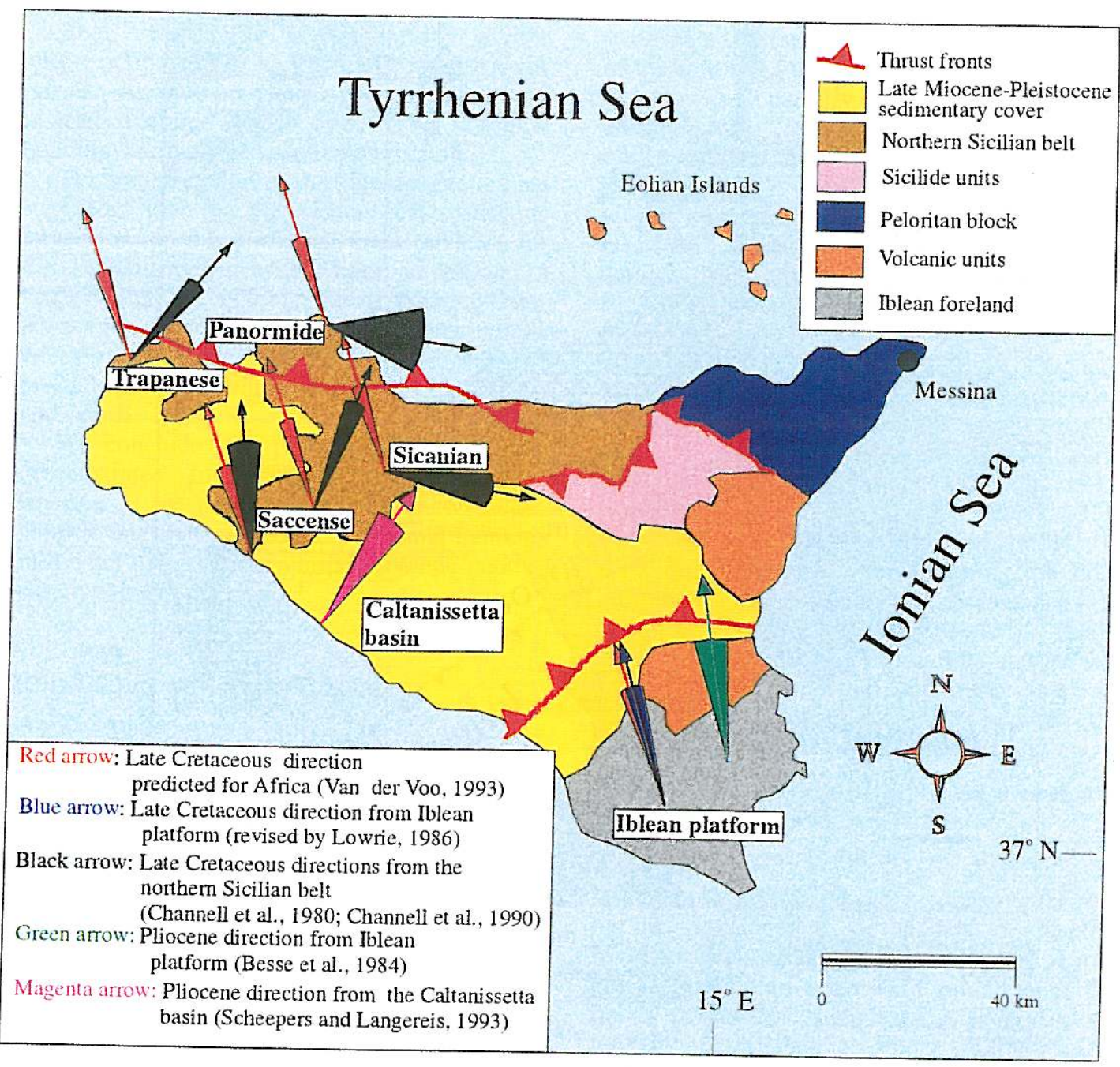

Fig. 8. Late Cretaceous and Pliocene paleomagnetic data from the Sicilian belt and the Iblean foreland. 
Pliocene sequences from the Caltanissetta basin near Eraclea Minoa (Scheepers and Langereis, 1993) indicate about $35^{\circ}$ of $\mathrm{CW}$ rotation since early Pliocene, $24^{\circ}$ of which younger than the Gauss/Matuyama boundary $(\sim 2.6 \mathrm{Ma})$ and $10^{\circ}$ during approximately Kaena times $(-3.05 \mathrm{Ma})$. This latter conclusion is not in agreement with the evidence for no rotation with respect to the Iblean platform found in the nearby Mesozoic sediments of the Saccense unit near Sciacca (Channell et al., 1990). We conclude that the overall pattern and timing of Neogene and Quaternary vertical axis rotations in allochthonous Sicily are not yet completely clarified and certainly merit to be further investigated.

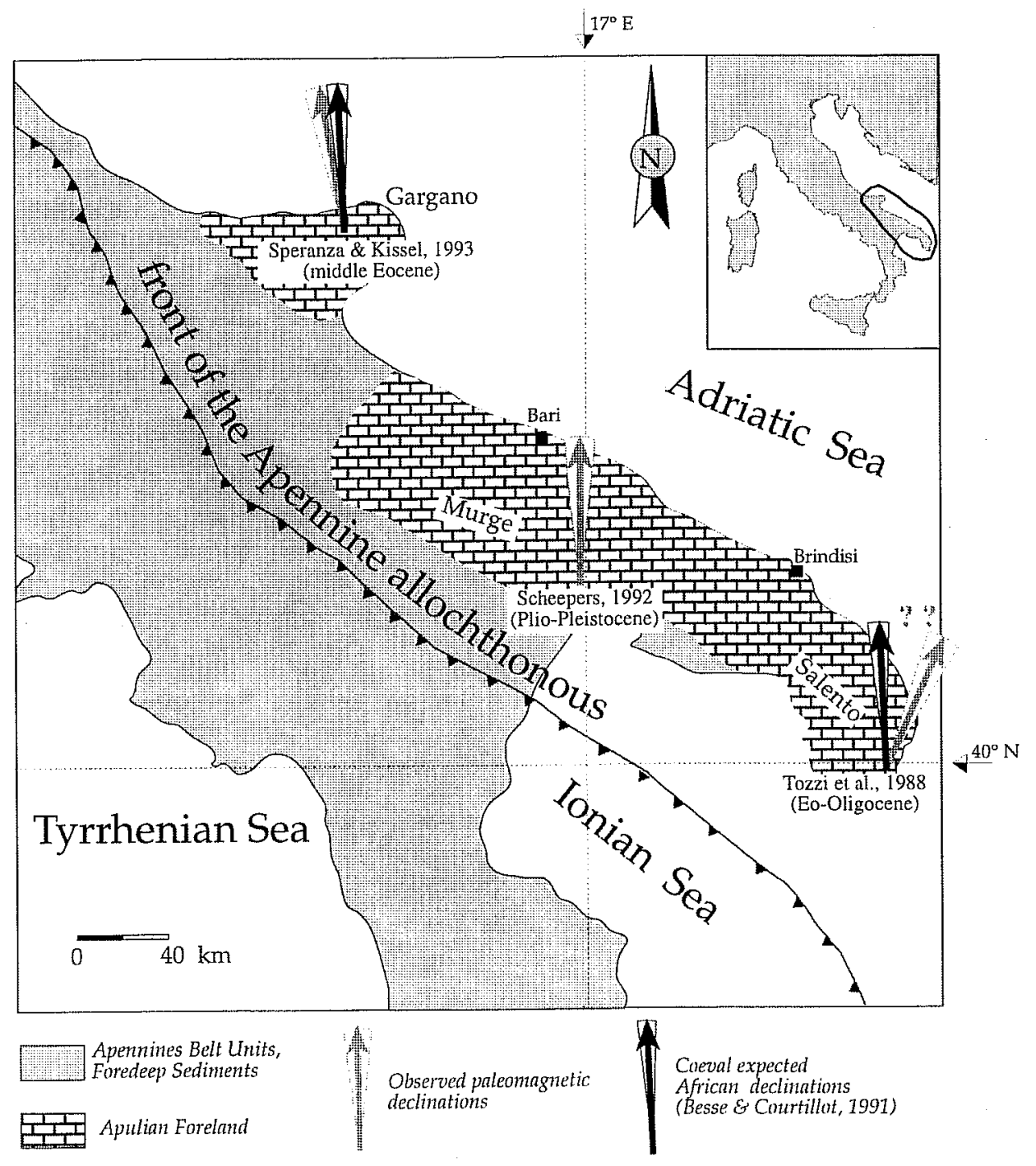

Fig. 9. Eocene - Pleistocene paleomagnetic data from the Apulia-Gargano foreland. 


\subsection{The peri-Tyrrhenian arc (Southern Apen- nines, Calabro-Peloritan block and Sicil- ian belt)}

Paleomagnetism was considered essential to unravel two main geodynamic features of the peri-Tyrrhenian arc:

1) to estimate the pattern of vertical axis rotations through tectono-stratigraphic units that belonged to different (internal to external) paleogeographic domains and underwent different amounts of orogenic transport toward the foreland;

2) to establish if the present-day arcuate shape of the arc is an original feature of the African-Adriatic continental margin or if it was instead acquired by a process of oroclinal bending during the Apenninic orogeny.

The interpretation of the paleomagnetic data suggested that (1) the amount of rotation is larger for the more internal units (at least for the Sicilian belt), which have undergone a large amount of tectonic transport (e.g., Catalano et al., 1976) and that (2) the ancient continental margin was much less arched than the present peri-Tyrrhenian arc (e.g., Incoronato and Nardi, 1989).

We conclude that point (1) is not clearly demonstrated for the Southern Apennines, whereas it is more evident in the Sicilian nappes, and that most of the oroclinal bending in the arc (2) is due to Plio-Pleistocene geodynamic events.

\subsection{Adriatic and Iblean foreland}

The Adriatic foreland has been subjected to broad paleomagnetic analyses since the mid seventies to test the geodynamical evolution of the whole Adriatic block.

Data from early and late Cretaceous carbonatic platform sequences from Gargano and Murge (Channell and Tarling, 1975, Channell, 1977; VandenBerg, 1983; Lowrie, 1986; Marton and Nardi, 1994) show, when compared to the most recent African APWPs, a slight $\left(\sim 10^{\circ}-15^{\circ}\right) \mathrm{CCW}$ rotation which is significant. Data from VandenBerg (1983) for the Gargano promontory were recently recomputed (Van der
Voo, 1993). At present the existence of a (slight) post-Cretaceous $\mathrm{CCW}$ rotation of the backbone of «Adria» with respect to the African plate is still controversial (fig. 9).

Paleomagnetic data from Eocene limestones in the Gargano promontory (Speranza and Kissel, 1993) can be interpreted either in terms of remagnetization or as evidence for no postEocene rotation of Gargano with respect to Africa. The data from the Eocene-Oligocene sediments in the Salento peninsula were interpreted as evidence for a $\mathrm{CW}$ rotation (Tozzi et al., 1988) but they are probably affected by widespread remagnetization (the significance of the fold test for the paleomagnetic data from Salento was critically reviewed by Bazhenov and Shipunov, 1991) and therefore they are not easily applicable to geodynamic reconstructions. Finally, data from Plio-Pleistocene clayey units in the Apulian foreland (Scheepers, 1992) show that no rotation has occurred since Late Pliocene (fig. 9).

The Iblean foreland in Sicily has been the focus of extensive paleomagnetic investigations since the seventies. The paleomagnetic data from Cretaceous, Neogene and Quaternary sediments and volcanics are not statistically different from the reference directions computed by the African APWP (Schult, 1973; Barberi et al., 1974; Gregor et al., 1975; Grasso et al., 1983; Besse et al., 1984). A slight $\left(\sim 10^{\circ}\right) \mathrm{CCW}$ rotation during the PlioPleistocene was attributed to extensional processes in the Pelagian Sea (Besse et al., 1984). Again, the uncertainties in the reference APWP for Africa and the usual confidence intervals related to paleomagnetic data hamper the sound identification of such slight rotations.

\section{Conclusions}

Paleomagnetism played a fundamental role in the development of models of Central Mediterranean geodynamic evolution. From the early simplex concept of «rotation of the Italian peninsula», thought of as a rigid block movement, the data gradually outlined a far more complex pattern of varied rotations that occurred mostly during the Neogene and Qua- 
ternary (that is they are coeval with the main geodynamic events) and differ for the various provinces distinguished on a geological basis. Differential vertical axis rotations are widespread in the region and were important for the genesis of present arcuate structures.

The available paleomagnetic data were critically reviewed in nine distinct sections: a comprehensive synthesis was not attempted since several geodynamic problems remain open and a regional link between the paleomagnetically detected vertical axis rotations and the main geodynamic events, as pointed out by classical geology, has yet to be soundly established.

\section{Acknowledgements}

We acknowledge Prof. Enzo Boschi for having encouraged this work. Fabio Speranza's work was supported by a EEC grant (contract EV5V-CT94-0464).

\section{REFERENCES}

Aïfa, T., H. Feinberg and J.P. Pozzr (1988): PliocenePleistocene evolution of the Tyrrhenian arc: paleomagnetic determination of uplift and rotational deformation, Earth Planet. Sci. Lett., 87, 438-452.

ALFONSI, L., L. SAGNOTTI and F. GALADINI (1995): Paleomagnetism of the Plio-Pleistocene continental sediments from the north-eastern edge of the Fucino basin (Central Italy), Annali di Geofisica, 38, 399-410.

Alvarez, W., S.G. Franks and A.E.M. NAIrN (1973): Paleomagnetism of Plio-Pleistocene basalts from North-West Sardinia, Nature, 243, 40-41.

ARGAND, E. (1924): La tectonique de l'Asie, in 13th International Geological Congress (Brussels), 171-372.

Barberi, F., L. CivetTa, P. Gasparini, F. Innocentt, R. SCANDONE and L. VILLARI (1974): Evolution of a section of the Africa-Europe plate boundary: paleomagnetic and volcanological evidence from Sicily, Earth Planet. Sci. Lett., 22, 123-132.

BAZHENOV, M.L. and S.V. Shipunov (1991): Fold test in paleomagnetism: new approaches and reappraisal of data, Earth Planet. Sci. Lett., 104, 16-24.

Besse, J. and V. Courtillot (1991): Revised and synthetic apparent polar wander paths of the African, Eurasian, North American and Indian plates, and true polar wander since $200 \mathrm{Ma}, J$. Geophys. Res., 96, 4029-4050.

Besse, J., J.P. Pozzi, G. Mascle and H. Feinberg (1984): Paleomagnetic study of Sicily: consequences for the deformation of Italian and African margins over the last 100 million years, Earth Planet. Sci. Lett., 67, $377-390$.

BobIER, C. (1974): La signification de l'aimantation rémanente des lave de la série «des ignimbrites inférieures» - conséquences pour l'étude de la rotation du bloc Corso-Sarde durant le Tertiaire, Rend. Sem. Fac. Sci. Univ. Cagliari, 43, 35-49.

Bobier, C. and C. Coulon (1970): Résultats préliminaires d'une étude paléomagnétique des formations volcaniques Tertiaires et Quaternaires du Logudoro (Sardaigne Septentrionale), C. R. Acad. Sci. Paris, 270, 1434-1437.

BUtLer, R.F. (1991): Paleomagnetism: Magnetic Domains to Geologic Terranes (Blackwell Scientic Publication), pp. 318.

CANDE, S.C. and D.V. KENT (1995): Revised calibration of the geomagnetic polarity timescale for the Late Creta. ceous and Cenozoic, J. Geophys. Res., 100, 60936095.

Catalano, R,, J.E.T. Channel. B. D'Argenio and G. NAPOLEONE (1976): Mesozoic paleogeography of the Southern Apennines and Sicily, Mem. Soc. Geol. It., 15, 95-118.

Channell, J.E.T. (1976): Umbrian paleomagnetism and the concept of the African-Adriatic promontory, Mem. Soc. Geol. It., 15, 119-128.

ChanNELL, J.E.T. (1977): Paleomagnetism of limestones from the Gargano peninsula (Italy), and the implications of these data, Geophys. J. R. Astron. Soc., 51, 605-616.

ChanNell, J.E.T. (1992): Paleomagnetic data from Umbria (Italy): implications for the rotation of Adria and Mesozoic apparent polar wander paths, Tectonophysics, 216, 365-378.

ChANNELl, J.E.T. (1996): Palaeomagnetism and palaeogeography of Adria, in Palaeomagnetism and Tectonics of the Mediterranean Region, edited by A. Morris and D.H. Tarling, Geological Society Special Publication, 105, 119-132.

Channell, J.E.T. and D.H. TARLING (1975): Paleomagnetism and rotation of Italy, Earth Planet. Sci. Lett., 25, 177-188.

Channell, J.E.T., W. Lowrie, F. Medizza and W. AlVAREZ (1978): Paleomagnetism and tectonics in Umbria, Italy, Earth Planet. Sci. Lett., 39, 199-210.

Channell, J.E.T., R. Catalano and B. D'Argenio (1980): Palaeomagnetism and deformation of the Mesozoic continental margin in Sicily, Tectonophysics, 61, 391-407.

Channel. I, J.E.T., J.S. Oldow, R. CATAlano and B. D'ARgenfo (1990): Palaeomagnetically determined rotations in the Western Sicilian fold and thrust belt, Tectonics, 9, 641-660.

Collinson, D.W. (1983): Methods in Rock Magnetism and Paleomagnetism (Chapman and Hall), pp. 503.

Coulon, C., A. Demant and C. Bobier (1974): Contribution du paléomagnétisme a l'étude des séries volcaniques Cenozoiques et Quaternaires de Sardaigne Nord-Occidentale, Tectonophysics, 22, 59-82.

DE Jong, K.A., M. MAnzoni and J.D.A. Zuderveld (1969): Paleomagnetism of the Alghero Trachyandesites, Nature, 224, 67.69.

De Jong, K.A., M. Manzoni, T. Stavenga, F. Van DijK, 
Neogene and Quaternary geodynamic evolution of the Italian peninsula: the contribution of paleomagnetic data

R. VAN DER VOO and J.D.A. ZUDERVELD (1973): Palaeomagnetic evidence for rotation of Sardinia during the Early Miocene, Nature, 243, $281-283$.

Dela Pierre, F., F. Ghisetti, R. Lanza and L. Vezzan1 (1992): Paleomagnetic and structural evidence of Neogene tectonic rotation of the Gran Sasso range (Central Apennines, Italy), Tectonophysics, 215, 335-348.

Duermeljer, C.E., N. VANVuGT and C.G. LANGerfis (1996): Reduction of major tectonic rotations by AMS: a case study from the Tyrrhenian arc, Annales Geophysicae, 14 (I), C149.

EDEL, J.B. (1979): Paleomagnetic study of the Tertiary volcanics of Sardinia, J. Geophys., 45, 259-280.

EDEL, J.B. and A. Lortscher (1977): Paléomagnetisme du volcanisme tertiaire de Sardaigne. Nouveaux résultats et synthèse, Bull. Soc. Geol. France, 19, $815-824$

Edel, J.B., R. Montigny and R. Thuizat (1981): Late Paleozoic rotations of Corsica and Sardinia: new evidence from paleomagnetic and $\mathrm{K}-\mathrm{Ar}$ studies, Tectonophysics, 79, 201-223.

El.DREDGE, S., V. Bachtadse and R. VAN DER VOO (1985): Paleomagnetism and the orocline hypothesis, Tectonophysics, 119, 153-179.

Fisher, R.A. (1953): Dispersion on a sphere, Proc. R. Soc. London Ser: A, 217, 295-305.

Funiciello, R., M. Parotto and A. Praturlon (1981): Carta Tettonica d'ltalia 1:1 500000 , CNR, Prog. Geodinamica, Publication No. 269, Roma.

Giallanella, P.R., A. Incoronato, E. Marsella and G. PAPPONE (1991): Paleomagnetic and geologic evidences for block rotations in the northern sector of Lagonegro basin (Southern Apennines), Mem. Soc. Geol. It., 47, 291-296.

Gialanella, P.R., F. Heller and A. Incoronato (1994): Rock magnetism of deformed Upper Triassic limestones from the Lagonegro Basin (Southern Apennines, Italy), Geophys. Res. Lett., 21, 2665-2668.

GLen, W. (1982): The Road to Jaramillo: Critical Years of the Revolution in Earth Science (Stanford University Press, Stanford, Calif.), pp. 459.

GORDON, R.G. (1995): Plate motions, crustal and lithospehric mobility, and paleomagnetism: prospective viewpoint, J. Geophys. Res., 100 (B12), 24367-24392.

GORDON, R.G. and G. ACTON (1989): Paleomagnetism and plate tectonics, in The Encyclopedia of Solid Earth Geophysics, edited by D. JONES (Van Nostrand Reinhold Company, New York), 909-923.

GRASSO, M., F. LENTINI, A.E.M. NAIRN and L. VigLIOTTI (1983): A geological and paleomagnetic study of the Hyblean volcanic rocks, Sicily, Tectonophysics, 98, 271-295.

Gregor, C.B., A.E.M. NAirn and J.R.W. Negendank (1975): Paleomagnetic investigations of Tertiary and Quaternary rocks. The Pliocene of Southeast Sicily and some Cretaceous rocks from Capo Passero, Geol. Rundsch., 64, 948-958.

HIRT, A. and W. LOWRIE (1988): Paleomagnetism of the Umbrian-Marches orogenic belt, Tectonophysics, 146, 91-103.

Horner, F. and W. Lowrie (1981): Paleomagnetic evidence from Mesozoic carbonate rocks for the rotation of Sardinia, J. Geophys., 49, 11-19.
INCORONATO, A. (1983): Paleomagnetic study of siliceous sediments from the Lagonegro nappes (Southern Apennines), Rend. Accad. Sci. Fis. Mat., 51, 12.

INCORONATO, A. (1988): Paleomagnetic evidence for preTertiary tectonic activity from Scisti Silicei formation, Lagonegro basin (Southern Apennines, Italy), Mem. Soc, Geol. It., 41, 1283-1289.

InCORONATO, A, and G. NARDI (1989): Paleomagnetic evidences for a peri-Tyrrhenian orocline, in The Lithosphere in Italy, Atti Conv. Acc. Naz. dei Lincei, edited by A. BORIANI et al., 80, 217-227.

InCoronato, A., D.H. Tarling and G. Nardi (1985): Paleomagnetic study of an allochthonous terraine: the Scisti Silicei formation, Lagonegro basin, Southern Italy, Geophys. J. R. Astron. Soc., 83, 721-729.

Incoronato, A., E. MARsella and G. PAPPONE (1988): Studio paleomagnetico nelle successioni lagonegresi affioranti tra Vietri di Potenza e Savoia di Lucania, in Proceedings $474^{\circ}$ Congresso Soc. Geol. It.», Sorrento 13-17 settembre, vol. A, 339-342.

IORIO, M. and G. NARDI (1988): Studi paleomagnetici sul Mesozoico del Matese occidentale, Mem. Soc. Geol. It., 41, 1253-1261.

JACKSON, K.C. (1990): A paleomagnetic study of Apennine thrusts, Italy: Monte Maiella and Monte Raparo, Tectonophysics, 178, 231-240.

Kligfield, R. and J.E.T. Channell (1979): Paleomagnetic evidence for large fault displacement around the Po-basin - discussion, Tectonophysics, 53, 139-146.

KLooTw1JK, C.T. and J. VANDENBERG (1975): The rotation of Italy: preliminary paleomagnetic data from the Umbrian sequence, Northern Apennines, Earth Planet. Sci. Lett., 25, 263-273.

LE Grand, H.E. (1989): Paleomagnetism and continental drift: historical introduction, in The Encyclopedia of Solid Earth Geophysics, edited by D. JoNEs (Van Nostrand Reinhold Company, New York), 901-909.

LowrIE, W. (1986): Paleomagnetism and the Adriatic promontory: a reappraisal, Tectonics, 5, 797-807.

Lowrie, W. and W. Alvarez (1974): Rotation of Italian peninsula, Nature, 251, 285-288.

Lowrie, W. and W. Alvarez (1975): Paleomagnetic evidence for rotation of the Italian peninsula, J. Geophys. Res., 80, 1579-1592.

LOWrIE, W. and W. Alvarez (1979): Paleomagnetism and rock magnetism of the Pliocene Rhyolite at San Vincenzo, Tuscany, Italy, $J$. Geophys., 45, 417-432.

LOWRIE, W. and A.M. HirT (1986): Paleomagnetism in arcuate mountain belts, in The Origin of Arcs, edited by F.C. Wezel (Elsevier, Amsterdam, 141-158.

MANZON1, M. (1974): Un'interpretazione dei dati paleomagnetici del Terziario della Sardegna ed alcuni nuovi esempi, Rend. Sem. Fac. Sci. Univ. Cagliari, 43, 163-167.

Manzoni, M. (1975) Paleomagnetic evidence for rotation of Northern Calabria, Geophys. Res. Lett., 2, 427-429.

MAnzonI, M. (1979): Paleomagnetic evidence for nonApenninic origin of the Sila nappes (Calabria), Tectonophysics, 60, 169-188.

Manzoni, M. and L. Vigliotti (1983): Further paleomagnetic data from Northern Calabria: their bearing on directions of emplacement of the Calabrian nappes, Boll. Geofis. Teor. Appl., XXV, 97, 27-43. 
Manzoni, M., K.A. De Jong, L. CArobene and G. Pasini (1972): Paleomagnetism of some basalts from Sardinia, G. Geol, 38, 5-9.

MARTon, E. and G. NARDi (1994): Cretaceous palaeomagnetic results from Murge (Apulia, Southern Italy): tectonic implications, Geophys. J. Int., 119, 842-856.

MARTON, P. and M. D'ANDrEA (1992): Paleomagnetically inferred rotations of the Abruzzi and Northwestern Umbria, Tectonophysics, 202, 43-53.

Mattei, M., R. FuniCiello and C. Kissel (1995): Paleomagnetic and structural evidence for Neogene block rotations in the Central Apennines, Italy, J. Geophys. Res., 100, 17863-17883.

Mattei, M., C. Kissel and R. Funiciello (1996a): No tectonic rotation of the Tuscan margin (Italy) since $\mathrm{Up}$ per Messinian: structural and geodynamical implications, $J$. Geophys. Res., 101, 2835-2845.

Mattei, M., C. Kissel, L. Sagnotti, R. Funiciello and C. FACCENNA (1996b): Lack of Late Miocene to Present rotation in the Northem Tyrrhenian margin (Italy): a constraint on geodynamic evolution, in Palaeomagnetism and Tectonics of the Mediterranean Region, edited by A. Morris and D.H. TARLING, Geological Society Special Publication, 105, 14l-146.

McElhinny, M.W. (1973): Palaeomagnetism and Plate Tectonics (Cambridge University Press), pp. 358.

MCFAdden, P.L. and R.T. MERRILL (1995): History of the Earth's magnetic field and possible connections to core-mantle boundary processes, J. Geophys. Res, 100 (B1), 307-316.

MerrilL, R.T. and M.W. MCELhinNy (1983): The Earths Magnetic Field: its History, Origin and Planetary Perspective (Academic, San Diego, California), pp. 401.

Montigny, R., J.B. Edel and R. Thurzat (1981): OligoMiocene rotation of Sardinia: $\mathrm{K}-\mathrm{Ar}$ ages and paleomagnetic data of Tertiary volcanics, Earth Planet. Sci. Lett., 54, 261-271.

Morris, A. and D.H. TARLING (1996), Palaeomagnetism and tectonics of the Mediterranean region: an introduction, in Palaeomagnetism and Tectonics of the Mediterranean Region, edited by A. MORRIS and D.H. TARLING, Geological Society Special Publication, 105, $1-18$.

NAIRN, A.E.M. and M. WestPhal. (1968): Possible implication of the palaeomagnetic study of Late Palaeozoic igneous rocks of Northwestem Corsica, Palaeogeog. Palaeoclimat. Palaeoecol., 5, 179-204.

NAIRN, A.E.M., G. NARDI, C.B. GRegor and A. INCORONATO (1985): Coherence of the Trapanese units during tectonic emplacement in Western Sicily, Boll. Soc: Geol. It., 104, 267-272.

OLdOW, J.S., J.E.T Channell., R. Catalano and B. D'Argenio (1990): Contemporaneous thrusting and large-scale rotations in the Western Sicilian fold and thrust belt, Tectonics, 9, 661-681.

OPDYKE, N.D. (1995): Paleomagnetism, polar wandering, and the rejuvenation of crustal mobility, I. Geophys. Res., 100 (B12), 24361-24366.

SAGNOTTI, L. (1992): Paleomagnetic evidence for a Pleistocene counter-clockwise rotation of the Sant'Arcangelo basin, Geophys. Res. Lett., 19, 135-138.

SAGNOTTI, L. and A. Meloni (1993). Pleistocene rotations and strain in Southern Italy: the example of the
Sant'Arcangelo basin, Annali di Geofisica, 36 (2), 83-95.

Sagnott, L., M. Mattei, C. Faccenna and R. FunlCIELLO (1994): Paleomagnetic evidence for no tectonic rotation of the Central Italy Tyrrhenian margin since Upper Pliocene, Geophys. Res. Lett., 21, 481-484.

ScheEPERS, P.J.J. (1992): No tectonic rotation for the Apulia-Gargano foreland in the Pleistocene, Geophys. Res. Lett., 19, 2275-2278.

ScheEPERS, P.J.J. (1994): Tectonic rotations in the Tyrrhenian arc system during the Quaternary and late Tertiary, Geol. Ultraj., 112, 1-352.

SCHEEPERS, P. and C.G. LANGEREIS (1993): Analysis of NRM directions from the Rossello composite: implications for the tectonic rotation of the Caltanissetta basin, Sicily, Earth Planet. Sci. Lett., 119, 243-258.

ScheEPERs, P. and C.G. LaNGEREIS (1994): Paleomagnetic evidence for counter-clockwise rotations in the Southern Apennines fold-and-thrust belt during the Late Pliocene and Middle Pleistocene, Tectonophysics, 239, $43-59$.

Scheepers, P., C.G. LANGereis and F.J. Hilgen (1993): Counter-clockwise rotations in the Southern Apennines during the Pleistocene: paleomagnetic evidence from the Matera area, Tectonophysics, 225, 379-410.

Scheepers, P., C.G. Langereis, J.D.A. Zijderveld and F.J. HILGEN (1994): Paleomagnetic evidence for a Pleistocene clockwise rotation of the Calabro-Peloritan block (Southern Italy), Tectonophysics, 230, 19-48.

Schult, A. (1973): Paleomagnetism of Upper Cretaceous volcanic rocks in Sicily, Earth Planet. Sci. Lett., 19, 97-100.

Schult, A. (1976): Palaeomagnetism of Cretaceous and Jurassic volcanic rocks in West Sicily, Earth Planet. Sci. Lett., 31, 454-457.

SPERANZA, F. and C. Kissel (1993), First paleomagnetism of Eocene rocks from Gargano: widespread overprint or non rotation?, Geophys. Res. Lett., 20 (23), 2627 2630.

Speranza, F., L. SagnotTi and M. Matrei (1997): Tectonics of the Umbria-Marche-Romagna arc (CentralNorthern Apennines, Italy): new paleomagnetic constraints, J. Geophys. Res., 102, 3153-3166.

Storetvedt, K.M. and N. Petersen (1976): Postulated rotation of Corsica not confirmed by new paleomagnetic data, J. Geophys., 42, 59-71.

Storetvedt, K.M. and L.A. Markhus (1978): Multivectorial magnetization in Late Paleozoic volcanics from North Sardinia; partial remagnetization and rotation, Geophys. J. R. Astron. Soc, 53, 245-257.

TARling, D.H. (1983): Paleomagnetism, Principles and Applications in Geology, Geophysics and Archeology (Chapman and Hall), pp. 379.

TODEsCO, M. and L. VIGLIOTTI (1993): When did Sardinia rotate? Statistical evaluation of the paleomagnetic data, Annali di Geofisica, 36 (5-6), 119-134.

TozzI, M., C. Kissel, R. Funiciellio, C. LAJ and M. Parotto (1988): A clockwise rotation of Southern Apulia?, Geophys. Res. Lett., 15 (7), 681-684.

VANDENBERG, J. (1983): Reappraisal of paleomagnetic data from Gargano (South Italy), Tectonophysics, 98, $29-41$.

VANDEnBerg, J. and A.A.H. Wonders (1976): Paleomag- 
netic evidence for large fault displacement around the Po-basin, Tectonophysics, 33, 301-320.

VAndenBerG, J. and J.D.A. ZiJoerveld (1982): Paleomagnetism in the Mediterranean area, Am. Geophys. Union, Geodyn. Ser., 7, 83-112.

VANDENBERG, J., C.T. KLOOTWIJK and A.A.H. WONDERS (1978): Late Mesozoic and Cenozoic movements of the Italian peninsula: further paleomagnetic data from the Umbrian sequence, Geol. Soc. Am. Bull., 89, 133-150.

VAN DER VOO, R. (1990): The reliability of Paleomagnetic data, Tectonophysics, 184, 1-9.

VAN DER VOO, R. (1993): Paleomagnetism of the Atlantic, Tethys and Iapetus Oceans (Cambridge University Press), pp. 411.

VAN DER VOO, R. and J.E.T. Channell (1980): Paleomagnetism in orogenic belts, Rev. Geophys. Space Phys, $18,455-481$

VANDIJK, J.P. and P.J.J. SChEEPERS (1995): Neotectonic rotations in the Calabrian arc; implications for a
Pliocene-Recent geodynamic scenario for the Central Mediterranean, Earth-Sci. Rev., 39, 207-246.

VigliotT, L. and D.V. Kent (1990): Paleomagnetic results of Tertiary sediments from Corsica: evidence of post-Eocene rotation, Phys. Earth Planet. Int., 62, 97-108.

Vigliotti, L. and V.E. LANGEnheIM (1995): When did Sardinia stop rotating? New paleomagnetic results, Terra Nova, 7, 424-435.

Vigliotti, L., W. Alvarez and M. MCWilliams (1990); No relative motion detected between Corsica and Sardinia, Earth Planet. Sci. Lett., 98, 313-318.

WeSTPHAL, M., J. ORSINI and P. VELLuTINI (1976): Le microcontinent corso-sarde, sa position initiale: données paléomagnetiques et raccords géologiques, Tectonophysics, 30, 141-157.

ZIJDERVELD, J.D.A., K.A. DE JONG and VAN DER VOO (1970): Rotation of Sardinia: paleomagnetic evidence from Permian rocks, Nature, 226, 933-934. 